\title{
Signs of YHWH, God of the Hebrews, in New Kingdom Egypt?
}

\author{
RACHELI SHALOMI HEN \\ The Hebrew University of Jerusalem, Israel
}

\begin{abstract}
This paper offers some observations on the meaning the Egyptians may have assigned to the name YHWA/YHA/YH, which is attested in lists of toponyms inscribed on temple walls dated to the time of the New Kingdom (1550-1069 BCE), and in a personal name of one owner of a Book of the Dead papyrus from around the same time. The paper examines the occurrences of names of Canaanite gods in Egyptian transcription, with special attention to orthography, through which it sheds new light on the Egyptian understanding of the name YHWA/YHA/YH.
\end{abstract}

KEYWORDS YHWH, toponyms, Shasu, Canaanite Gods, Anat, Baal, Astarte, Qedeshet, Reshef, Dagon, Seth, classifiers

\section{Introduction}

The nature of the name YHWA/YHA/YH, attested in a number of Egyptian records dated to the time of the New Kingdom (1550-1069 BCE), attracted much scholarly attention since it was first published in 1947 (Grdseloff 1947). YHWA/YHA/YH appears primarily, but not exclusively, in lists of toponyms inscribed on Egyptian temple walls that record the subdued enemies of the Pharaoh. In three of these attestations, YHWA follows the compound Ta-Shasu (the land of the Shasu), and once even in association with $S$ rrr, understood by many scholars to be the Biblical Seïr, the place from which YHWH, the god of the Hebrews, originated (see Deut 33:2; Judges 5:4). ${ }^{1}$

There is no doubt that the name YHWA/YHA/YH in New Kingdom toponym lists is a geographic reference. However, the biblical tradition, the role of Egypt in the story of the Exodus, and the attestation of the name YHWA in association with the West Semitic Shasu and Seïr aroused much curiosity and even hopes among scholars. Here, they thought, is Egyptian evidence for the acquaintance of the Ancient Egyptians with the biblical god of the Hebrews

1 It is important to stress that understanding Seïr as the place of origin of the Biblical YHWH is a common scholarly interpretation; however, it is not stated directly in the text. 
YHWH (Kennedy 2019). ${ }^{2}$ A number of scholars suggested that the name YHWA/YHA/YH may also be the Egyptian transcription of the name of YHWH, god of the Hebrews. They further believed that the location mentioned on the toponym lists was named after YHWA/YHA/YH as a divine being (Smith 2017; Kennedy 2019; Miller 2021, 87-88; Flynn 2020, 34), whereas others denied the divine nature of the Egyptian inscribed YHWA altogether (Fleming 2021, $1-2,221)$.

The current paper will not solve this puzzle. It will merely offer a comment on the meanings that may have been assigned to the name YHWA/YHA/YH by the Egyptians in the time of the New Kingdom, by looking at the names of Canaanite gods in Egyptian records. The first part of this paper will survey the existing evidence for YHWA/YHA/YH, whereas the second part will be dedicated to the examination of some Canaanite gods' names in Egyptian transcription in light of the YHWA/YHA/YH attestations, from which the Egyptian understanding of the name can be deduced.

\section{The Name YHWA/YHA/YH in Egyptian Sources}

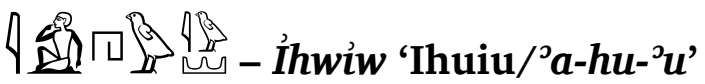

The attestation of 4 造四 overseer of the quarries, dated to the Eleventh Dynasty (ca. 2000 BCE). ${ }^{3}$ Although this attestation is too early for the time frame set for this paper, it is discussed here because some

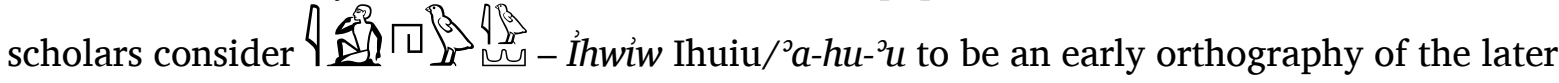
YHWA/YHA/YH (Giveon 1964).

On his biography, $\underline{H} t y$ gives the following acount:

[1.9] (...) I returned in peace to his (the king's) palace (ch.f) and brought him the best of the foreign lands in new metal from Bau(t), [1.10] shining (psd $)$ metal from

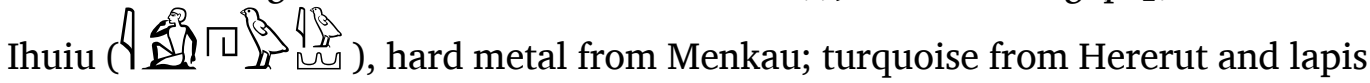
lazuli from Tefreret, [1.11] best Saherut from the mountains, Khetauau from the mountain of Hesa/Heset; Ranetjet from Baq-[1.12] Desheret, staffs (mdw.w) from Rashaut and Mesdjemet from Kehebu. ${ }^{4}$

Alan Gardiner, who first published this inscription, suggested that the region in which $\underline{H} t y$ conducted his mining operations was the Sinai Peninsula (1917, 36). Gardiner, however, did not even mention the possibility that Hebrews. The first to associate 4 造 who suggested that this orthography was an older form of the name YHWA/YHW/YHA, which was listed in the Temples of Soleb, Amara West, and Medinet Habu (Giveon 1964, 244-45). ${ }^{5}$ On grounds of comparative phonology, namely the transcription system of James

2 For discussion and bibliography, see Adrom and Müller (2017).

3 For the stela, see Gardiner (1917, 28-38). For further information and discussion, Adrom and Müller (2017, 94-95).

4 For this translation, and the Egyptian spelling of all place names appearing in this passage, see Adrom and Müller (2017, 94).

$5 \quad$ For Amara West, Soleb and Medinat Habu, see below. 
Hoch (1994, 487-504), Faried Adrom and Matthias Müller argued in their detailed article that 4 造四 should be transcribed as ${ }^{\circ} a-h u^{-} u$ rather than Ihuiu, and therefore should be eliminated from the discussion (Adrom and Müller 2017, 95). ${ }^{6}$ As for the attempts to identify the region under discussion, Adrom and Müller stressed that "since Khety mentions that he delivers the commodities from Ihuiu to the 'palace of Pharaoh' without giving any details whence and how he obtained these, any deliberations about the location of Ihuiu as well as the other mentioned toponyms are mere speculations" (2017, 94-95).

Notwithstanding whether 4 年 clear that in this context and in this orthography, the name is a name of a place, even if its exact location cannot be ascertained.

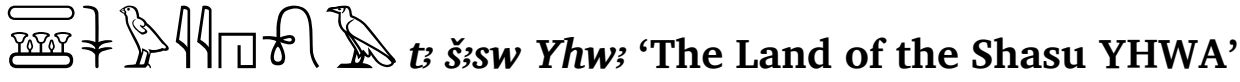

Considerably later than the above-mentioned 4 年 different context, there are two attestations of the name YHWA in the temple of Soleb in Nubia, ${ }^{7}$ built by King Amenhotep III (1390-1352 BCE). ${ }^{8}$ The first is Sb. 69, an isolated block, part of a destroyed list of toponyms. ${ }^{9}$ Another fragment, $\mathrm{Sb} 79$, is to be found in section IV of the main hypostyle hall, on column IV N4. It constitutes part of a list of toponyms, which apart from bearing the name $t ; \check{s}_{s} s w Y h w_{3}{ }^{10}$ 'The Land of the Shasu YHWA,' bears the names $t$; šsw Trbr 'The Land of the Shasu Trbr'; $t$ šs sw Smt 'The Land of the Shasu Smt,' and possibly $B t$ ' $n[t]$ 'Beit Anat.' 11

All attempts to identify the exact location of YHWA from the position of the name within the list, or within the hypostyle hall, proved futile (Adrom and Müller 2017, 96-97; Fleming 2021, 57-61). In his recent book, Yahweh before Israel: Glimpses of History in a Divine Name, Daniel Fleming explains that, for the Egyptians " $[. .$.$] the Shasu were people of the wilderness,$ who could live without cities. This land wrapped around the more settlement-oriented coast and highlands that ran north and south across the Levant, opening into space to the east and south. All the individual units of 'Shasu-land' in the early fourteenth century, including Yhw3, can only be placed somewhere in this back country, beyond easy Egyptian reach" $(2021,61) .{ }^{12}$ In other words, the Shasu are known from Egyptian records to be a West Semitic nomadic population wandering in the Syro-Canaanite region, Sinai, and the Transjordan since the fifteenth century BCE (Weippert 1974, 270-73; Redford 1992, 269-75). ${ }^{13}$ Hence it appears that The Land of the Shasu YHWA must be located somewhere within these boundaries.

$6 \quad$ For detailed discussion and further bibliography, see Adrom and Müller $(2017,95)$.

7 For a very recent and thorough discussion of the Soleb attestations, see Fleming (2021, 30-40).

8 Dates are taken from Shaw (2000, 479-83).

9 Giveon (1964); Schiff Giorgini and Robichon (1998, 179); Schiff Giorgini and Robichon (2002, pls. 206207).

The reading of the last sign as EG G1 'A' rather than G43 'w' (as it appears in Fleming 2021, 24, fig. 1) is based on new photographs and an examination of the inscriptions by Kennedy $(2019,184)$.

11 On this reconstruction, see Adrom and Müller (2017, 105, n. 84); for a high-quality photo of this fragment, see Kennedy (2019, 180, fig.3). Against this reading, see Schiff Giorgini and Robichon (2002, pl. 221), who suggested Beit Af [...] since they interpreted the sign in question as ' $\mathrm{f}$ ' rather than an Ayin. For other attestations of Beit Anat in Egyptian toponym lists, see below. On the geography of the Shasu, see Weippert (1974, 270-73); Redford (1992, 269-75). For further bibliography concerning the Land of the Shasu, see Morris (2005, 221. n 12). 


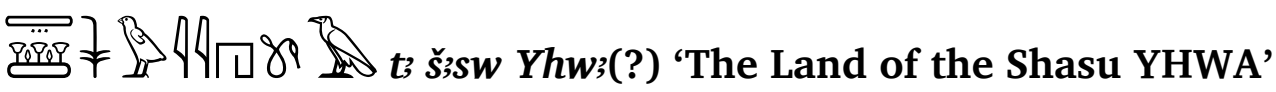

This attestation comes from the temple of Amara-West, built by King Ramesses II (1279-1213 BCE), also in Nubia, some $50 \mathrm{~km}$ north of Soleb. ${ }^{14}$ There, the name $t$ s šsw Yhw' 'The Land of the Shasu YHWA' appears as part of a topographical list naming Northern enemies and Northern place names. The list is part of the decoration of the temple's Hypostyle Hall, and together

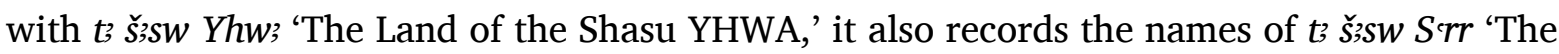

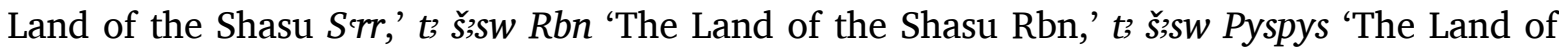
the Shasu Pyspys,' $t$; $\check{s}$ ssw Smt 'The Land of the Shasu Smt' and $t$ s $\check{s}$ ssw [T]rbr 'The Land of the Shasu [T]rbr' (KRI II, 217(10): 92-97). ${ }^{15}$

Many scholars see $S r r$ within the compound $t$ ' $\check{s}$ ssw Srrr 'The Land of the Shasu Srr,' which opens the sequence $t$ šssw [...] 'The land of the Shasu [...],' as an attestation of the Biblical name Seïr. In the same sequence, Shasu YHWA' appears in the fifth place (KRI II, 217(10): 92-97). The association between Seïr and YHWA in an Egyptian record was perceived by some as a confirmation of the identity of YHWA in the Egyptian lists with the Biblical YHWH, as an Egyptian attestation of the Tetragrammaton. Moreover, the appearance of Seïr, the very place from where the Biblical YHWH possibly originated (see Deut 33:2; Judges 5:4) seems to indicate that t3 $\check{s}_{3} s w$ Yhw'(?) 'The Land of the Shasu YHWA' is located in the south of the Transjordan or the south of Canaan, since Biblical Seïr and Biblical Edom are used as synonymous poetic pairs. ${ }^{16}$ Consequently, the supporters of the Kenite/ Midianite Hypothesis see the mention of Seïr in the Amara-West list as a further validation of the southern origin of YHWH god of the Hebrews. ${ }^{17}$

On orthographical grounds, the identification of $S \mathrm{sr}$ with the Biblical Seïr is not free of impediments, and it is far from being certain (Adrom and Müller 2017, 99-101). Even if one is willing to believe that $S$ rr of Amara-West and the Biblical Seïr are one and the same, there are difficulties within the Egyptian documents. Fleming claims that the names of the Shasu groups as recorded in Soleb and in Amara-West represent groups of people not identified by towns or specific geographical places. The individual Shasu units, according to him, were most easily understood to derive from indigenous social and political organization, which Egyptian scribes could render collectively by the kinship term $m h w t$, often translated as 'family' (Fleming 2021, 48-49). Fleming believes that the Egyptian contact with specific Shasu groups must come from the reign of Amenhotep III (1390-1352) or earlier (Fleming 2021, 51). Assuming the list of Amara-West was based on that of Soleb, or another fifteenth- to fourteenth-century topographical list, Fleming conducted an elaborate work of calculation and reconstruction on the Soleb fragments, and since the remaining gap within the Soleb list could not have accommodated 'Seïr,' Fleming concludes that Seïr was probably a later addition (Fleming 2021, 41-44). Furthermore, he maintains that "[...] the Shasu references from the $15^{\text {th }}$ and early $14^{\text {th }}$ centuries lack entirely the deep southern orientation of the $13^{\text {th }}$ and $12^{\text {th }}$ century texts,

14 For a recent discussion of the attestation in Amara West and for a comparison with the Soleb attestations, see Fleming (2021, 40-45).

15 KRI = Kitchen, Ramesside Inscriptions (1968-1983).

16 For the view that The Land of the Shasu of YHWA is located within Edom-Seïr, see Miller (2021, 87).

17 For recent discussions of the Midianite/Kenite Hypothesis and the possible southern origins of YHWH, see Fleming (2021, 67-110); Miller (2021, 18-60). For a radically different view on the origins of the Biblical YHWH, see this volume Frevel (2021). 
with their links to Seir and Edom" (Fleming 2021, 57). In fact, Fleming explains that in the earlier phases of Egyptian involvement in the Levant, when Egypt was trying to consolidate its grip in the entire region, the geographical associations of the Shasu were mostly northern rather than southern (Fleming 2021, 61). Consequently, he claims, 'The Land of the Shasu of Seïr' in the thirteenth century Amara-West list reflects the concurrent Egyptian involvement in the deep south of the Levant during the thirteenth and the twelfth centuries, after they have lost their hold in the north. Hence, Seïr in Amara-West did not point to a specific location associated with the origins of YHWA (of the Egyptian inscription)/ YHWH (the biblical god) (Fleming 2021, 61).

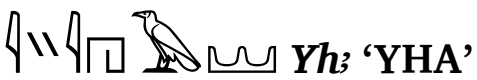

The name 'YHA' appears twice on the southern tower of the first pylon at Medinet Habu, ${ }^{18}$ the mortuary temple of King Ramesses III of the Twentieth Dynasty (1184-1153 BCE), built on the west bank of the Nile in Thebes (modern Luxor). The first of these attestations is part of a long list of 125 cartouches encircling names. This long list consists of three groups, the third of which contains cartouche no. 115 in which the name A" grouped together with place names in Canaan. According to Michael Astour, all the names in the third group are identifiable as locations in modern Lebanon and Syria (Astour 1979, 24 28). This assertion, however, is not accepted by all scholars, and many still opt for locations in southern Canaan. ${ }^{19}$

The other attestation also appears on the southern tower, in a short list compiled randomly from the longer list. ${ }^{20}$ The orthography of both attestations in Medinet Habu is the same. Giveon was the first to associate 4 " discussed

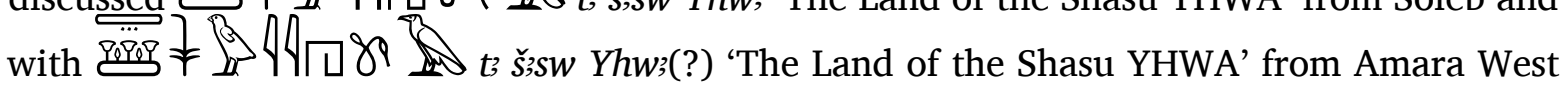
(Giveon 1964, 244). Nevertheless, it is not clear whether Yh' 'YHA' should be sought in the Northern regions of Syria and Lebanon or in Southern Canaan. However, one should stress the fact that here, as in the earlier attestations, $Y h$ is clearly a place name.

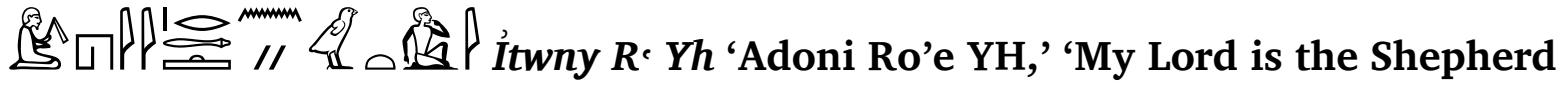 of Yah'}

The word $\mathrm{YH}$ in this case is very different from those discussed above, since its context and co-text do not dictate its meaning as a place name. ${ }^{21}$ According to Thomas Schneider, it is the first documented occurrence of YHWH in his function as a shepherd of Yah (Schneider 2008, 117-18 §4). Here 'YH' appears as part of the owner's name in a Book of the Dead papyrus, dated to the late Eighteenth or the Nineteenth Dynasty (ca. 1330-1230 BCE) (Schneider 2008, 114). Reading $\mathrm{YH}$ as a short form of $\mathrm{YHWH}$ is supported by the Biblical evidence, ${ }^{22}$ and by Giveon's reading of 4 "

18 See Breasted (1932, pls. 101, 104-105).

19 For discussion and further bibliography, see (Adrom and Müller 2017, 104-8).

20 See Simons (1937), list XXIX, 84, and no. 13 at 174.

21 See variant 3 in Schneider $(2008,115)$.

22 For Biblical reference, see Schneider $(2008,117)$. 
with

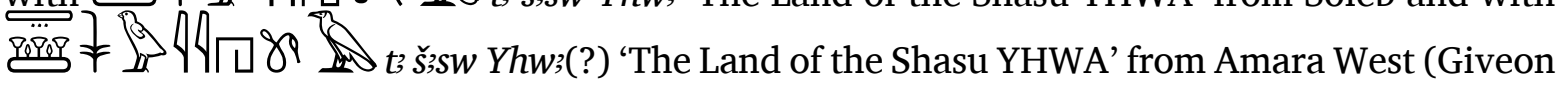
1964, 244). Schneider further suggests that the full name constitutes an Egyptian transcription of a Northwest Semitic theophoric sentence name, 'Adoni Ro'e Yah' 'My Lord is the Shepheard of Yah. ${ }^{23}$ Yah, according to Schneider, is a toponym that later was used as a divine name, whose long form is attested in Egyptian toponym lists. Later it was used as the name of the Biblical deity YHWH (Schneider 2008, 119).

According to this interpretation, albeit its exceptional context, $\mathrm{YH}$ is a toponym, and from the perspective of this paper, it is not very different from the various attestations discussed above. $^{24}$

Having surveyed all attestations of the name YHWA/YHA/YH, it appears that the first four are clear geographical references. It is also clear that the last example, that of

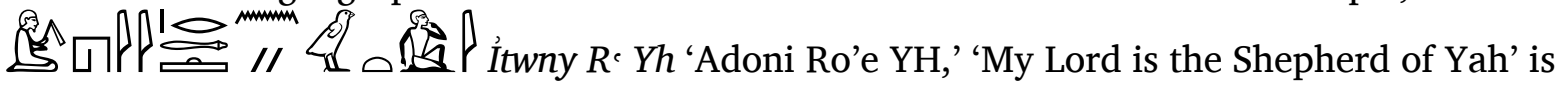
a northwest Semitic theophoric name whose exact signified is unknown.

Of course it is possible to hypothesise that 'The Land of the Shasu YHWA/YHA/YH' stands for a cult center (Görg 1976), but recent scholarly discussions offer slightly different and more elaborate solutions. Miller, for example, understands the compound 'The Land of the Shasu YHWA' as a place name with a reference to a spiritual being (Miller 2021, 86). Moreover, "It is unclear if Yahweh the place name refers to a tribe, region, or settlement, but since we are able to localize the Yahweh of the Shasu-Yahweh in Edom-Seir, the name itself is making the same claim about that territory [...] at a minimum, the Southland belongs to God. By naming, someone [...] has given the place called 'Yahweh' a social function: not simply 'where Yahweh was known,' but 'this place is Yahweh's'" (Miller 2021, 87). Miller continues to finetune his argument by claiming that although we have no evidence of YHWA as the god of the Shasu, we may conclude that the connection between the biblical god YHWH and the southern part of modern Israel, southwestern Jordan, and northwestern Saudi Arabia, is firmly planted in the Late Bronze and Early Iron Ages (Miller 2021, 88).

On the basis of an analysis of eleventh to tenth century BCE South Arabian material, Fleming suggests that the fourteenth and thirteenth century BCE Egyptian inscribed YHWA was indeed a name of a Shasu group, which may have been named after an ancestor or another person in familial or kinship terms (Fleming 2021, 235). He explains that South Arabian notions of political unity from divine descent could provide a framework for understanding how the name of the Shasu group YHWA of the Egyptian evidence became YHWH, the Biblical god of the Hebrews, some centuries later (Fleming 2021, 244). ${ }^{25}$

Was the Egyptian inscribed YHWA a divine name? Did 'The Land of the Shasu YHWA' refer to a place or to a people? Was it a specific point on the map, or maybe a region? Was it an ancestral name? Was it a name of a tribe? ${ }^{26}$ Unfortunately, albeit the interesting analogies, the

23 For a thorough discussion and reasons for this interpretation, see Schneider (2008, 113-20).

24 For a slightly different interpretation, see Fleming (2021, 63-64), who argues that "[...] the personal name 'adōnī-rō'ē-yāh would reduce the plausibility of a conclusion that Yhw3 already represented the deity Yahweh, identified with a named group, or people. It is the people, not a god, that need a 'shepherd.' Most simply, Yhw3 is one subdivision of some association of groups that the Egyptians during or before the reign of Amenhotep III considered to constitute a territorial 'Shasu-land.' " Please note the elaborate discussion on South Arabia and Moab, especially the term $\mathrm{cm}$ and its Biblical expression $\mathrm{m}$ Yhwh in Fleming (2021, 238-44).

26 Similar questions may be raised concerning another set of names appearing in Egyptian topographical lists of Ramesses II in Karnak and of Ramesses III in Medinet Habu, namely the names prefixed by $k s: k s r$, 
learned discussions, and the broad perspective, the evidence is too scanty to allow any conclusions concerning the exact meaning of the term YHWA/YHA/YH as it appears in Ancient Egyptian records.

\section{West Semitic Divine Names in Egyptian Sources}

As suggested by the Egyptian evidence, YHWA/YHA/YH was undoubtedly a geographical reference. However, the question whether it was also perceived as a divine being in Egypt remains open. In an attempt to deal with this issue, one should first turn to Egyptian expressions of veneration towards Canaanite gods. Egyptian royal monuments bearing the names and figures of Canaanite deities are well known and were treated in detail in the past. ${ }^{27}$ None of them, however, mentions YHWH. In what follows I shall start with a brief examination of personal stelae dedicated to Canaanite gods; then we shall proceed to toponyms that include names of Canaanite deities; and finally, we shall look at Egyptian theophoric names constructed with Canaanite theonyms.

The Egyptians developed a system of transcribing foreign words (Hoch 1994, 399-504) within which they retained the use of Egyptian classifiers (known in older literature as 'determinatives'), that is, hieroglyphic signs which add semantic value to the word they follow (Goldwasser 2002, 7-24). In this capacity, classifiers can mark categories. For example, words which belong to the category 'house,' such as 'house,' 'room,' 'interior,' or even 'tomb,' may be followed by the house sign $\square-\left(E G\right.$ O1). ${ }^{28}$ Another example is the 'water' category, where one may find words such as 'well,' 'wave,' 'wash,' 'thirsty,' or 'drink,' which may be followed by the hieroglyph for water ${ }_{m}$ including toponyms, they added classifiers that suited the meaning of the words in their original language. ${ }^{29}$ For example, the Egyptian transcription to the West Semitic toponym 'Beit Sopher,' which literally means 'House of Scribe' I is classified by $\square$ for the word 'Beit' - 'house,' and by 图学, a scribal kit (EG Y3), for the word 'sopher' - 'scribe,' in spite of the fact that these were Canaanite nouns. It is important to stress, however, that the use of classifiers is not mandatory; they may be dropped and left out, and hence, the lack of classifier does not necessarily indicate a change of meaning.

Of particular interest for this study is the category 'divine,' which was mostly marked in the time frame set for this paper by both the seated bearded man 1 ? (EG A40) as a male divine classifier and the cobra (EG I12) as a female divine classifier (Shalomi-Hen 2000, 61-64). Thus, names of deities may be followed by 1 or 2 , in agreement with their gender. Part and parcel of the group of divine classifiers are the individual logograms of many Egyptian deities,

ksspt, kssnrm, and ksrbn. These are believed by some to be the earliest record of the Edomite god Qaus, whose next appearance is dated to the eighth century BCE. According to Oded $(1971,50)$ " [...] we may reasonably assume that the names under discussion represent Edomite chiefs or clans, each one bearing a name composed of the theophoric קום." See also Knauf $(1984,1999)$. For a discussion about the Edomite Qaus and YHWH, see Kelley (2009).

27 See, among others, Tazawa (2009, 137-48).

$28 \quad E G=$ sign list in Gardiner (1957).

29 For examples, see Giveon $(1978,15-21)$.

30 See Papyrus Anastasi I, 1.22 .5 in Gardiner (1911, 66-68). See also Hoch (1994, 364); Giveon (1978, 19-20). 
which either follow the deity's name or replace it altogether. Fine examples are the sign of a woman with a feather on her crown (EG C10) for the goddess Maat, the sign of an ibis on a standard $\frac{3}{4}(E G$ G26) for the god Thoth, and the sign of the woman wearing a crown

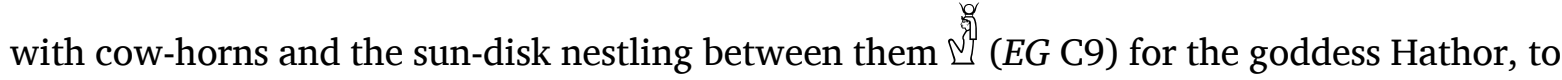
mention just a few. Generally speaking, this group of signs is hardly relevant to the current discussion, since the individual divine logograms are, in fact, small pictures of the different Egyptian deities and almost none of them ever represents a foreign deity.

However, an exception to this rule are the signs depicting the Egyptian god Seth E21) and (EG E20), which came to represent the Semitic Baal. ${ }^{31}$ The unprovenanced private stela of a man named Af _ Mswtw 'Mesutu' (Metropolitan Museum: MET O.C. 679) is an interesting case in point. The stela is dated to $1550-1400 \mathrm{BCE},{ }^{32}$ and is a typical funerary stela, bearing an ordinary offering formula and dedicated to the Egyptian god Sokar-Osiris. Yet, it is of relevance since the name of the owner is a theophoric name, formed with the name of the Canaanite god Baal. Itw'w 'Itu'u' may be an Egyptian transcription of the Semitic root ע.ד.' 'to know.' Hence it is possible that the owner's name means 'The Aquaintance of Baal,' which may indicate the owner's Semitic origins. ${ }^{33}$

The most significant detail from this study's point of view is the orthography of the name Itu'u-Baal. The name of the owner appears twice on the stela, once as part of the offering formula $A$ A Af 13 . The variations are indeed minor and common in Egyptian orthography. Yet, it is noteworthy that the name of Baal, which forms part of the owner's name, is written differently- 20 in the offering formula, and 5 figure.

The signs 5 (EG E21) and (EG E20) are known in Egyptology as the 'Seth animal.' In the Egyptian pantheon, Seth is the god of the foreign lands and of storm (Te Velde 1967, 128; Allon 2007). Controlling the weather was one of the chief concerns of the Canaanite Baal, and was one of the reasons for the Canaanite Baal and the Egyptian Seth to become identified with each other in the times of the Egyptian New Kingdom (Allon 2007). A wellknown expression of these syncretistic ideas is the 400 Years Stela, erected by King Ramesses II (thirteenth century BCE), where the Egyptian god Seth is iconographically represented as the Semitic god Baal, ${ }^{34}$ also known as the Asiatic Seth. ${ }^{35}$ Another expression of the syncretism between the Canaanite Baal and the Egyptian Seth is the Egyptian orthography of the name of Baal, which in the time of the New Kingdom always employs or on its own, standing for the word Baal, ${ }^{36}$ much like in the name of the above discussed

31 On the process of the assimilation between Seth and Baal, see Allon (2007).

32 See Hayes (1990, 170); Stela of Itubaal and Masutu, from The Metropolitan Museum of Art: https://www. metmuseum.org/art/collection/search/554792, last accessed 27 December, 2021.

33 For the name and Semitic parallels see Schneider (1992, nos. 111, 63); Hoch (1994, nos. 64, 58).

34 For discussion and further references, see Stadelmann (1967, 41-42; Te Velde 1967, 124-26; Allon 2007).

35 For the Asiatic Seth and further references, see Levy (2014, 305-6).

36 See Stadelmann (1967, 35); Leitz (2002, 2:778). 
Itu'u-Baal. ${ }^{37}$ For all these reasons, the name of Baal, when written with the Seth animal either as a classifier or as a logogram, will also be considered in the following discussion.

\section{West Semitic Divine Names on Egyptian Private Stela}

The most obvious source for Egyptian use of divine classifiers in Canaanite divine names is the corpus of Egyptian private stelae. These monuments were dedicated by private people whose religious sentiment to the deity in question is beyond doubt. Among many private stelae dedicated to Egyptian gods, we find a group of stelae dedicated to Canaanite gods, inscribed in Egyptian.

One of the most famous examples is the Turin Stela (no. 50066) (Cornelius 2008, cat. No. $5.3,124)$ dated to the reign of Ramesses II of the Nineteenth Dynasty (thirteenth century BCE). It bears a relief of the foreign goddess Qedeshet standing on a lion, ${ }^{38}$ MinAmun-Re to her right, and Reshef to her left. ${ }^{39}$ Like many stelae of this type, it was found at the workers' village of Deir el-Medina, ${ }^{40}$ and this particular stela was dedicated by the workman Ramose. The name of Qedeshet with her epithets is written above her figure: ure: 'Qedesh[et] Lady of Heaven, Mistress of All Gods, The Eye of Re, Who has no Equal.' Immediately after the name Qedeshet, a cobra sign was inscribed, marking her as a goddess.

Reshef, another Canaanite god, who constitutes part of this triad, stands to her left. His name is written with his epithets above his figure:

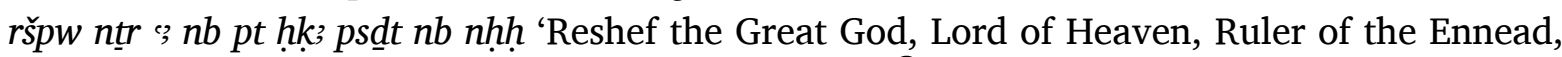
Lord of Eternity.' Here too, the male divine classifier $\$$ f follows the name of Reshef, indicating that he belongs to the divine category. ${ }^{41}$ It is worthwhile noting that the Turin Stela is not a unique example. Stelae dedicated to the triad of Qedeshet, Min-Amun-Re and Reshef are well known from the time of Ramesses II, and are probably related to fertility (Tazawa 2009, 165-67).

An illuminating example of the worship of Canaanite deities in Egypt is that of the Winchester Stela (Cornelius 2008, cat. No. 5.16, 128) bearing the name

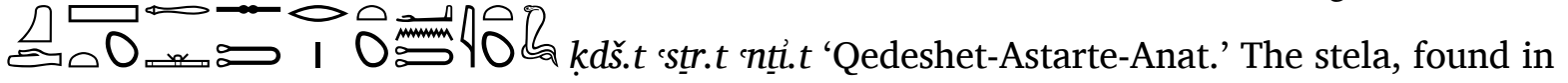
Deir el-Medina, ${ }^{42}$ is dated to the reign of Ramesses III (twelfth century BCE) (Budin 2015, 1), and was dedicated by the workman Neferhotep. The name $k d$ š.t 'str.t nți.t 'Qedeshet-Astarte-Anat' is written around the figure of a naked goddess, standing on a lion, very similar to the Qedeshet figure of the Turin triad mentioned above.

37 On the association of the Egyptian god Seth with foreigners and foreign gods, see Te Velde (1967, 109-51); Taylor (2016, 128-29).

38 For the iconography of Qedeshet and its origins, as well as reference to objects on which she appears, see Budin (2015).

39 On the triad of Qedeshet, Min and Reshef, see Cornelius (2008, 48-50, 121-27 and cat. No 5.1-13, and plates);Tazawa (2009, 165-67).

40 On the worship of Canaanite gods in Deir el-Medina, see Tazawa (2009, 1-2).

41 For reference to this stela and other stelae of the triad, see Cornelius (2008, cat. No 5.1-13, 48-50, 121-127 and plates); Tazawa (2009, 165-67). For other attestations of Reshef, see Helck (1962, 485-89). See n. 40 . 
Here the goddess appears on her own, and her name is a merging of the names of three Canaanite goddesses united in one figure (Edwards 1955). Again, at the end of the string of the three merged names appears the cobra sign $\sqrt{3}$, which indicates that the figure in question is a goddess.

Mekal Stela from Beit Shean, dated to the Nineteenth Dynasty (thirteenth century BCE), ${ }^{43}$ is an interesting case in point. The name of Mekal with his epithets is carved in a low relief above the figure of the god: Great God [Lord of] Beit Shean' (Levy 2018). The god is depicted seated on a throne, bearing iconographic characteristics of both the Canaanite gods Baal and Reshef (Levy 2018, 368). Although it was found in Beit-Shean in the Jordan Valley, it was erected in memory of the Egyptian architect Amenemopet by his son Paraemheb, to honour the local god Mekal. In fact, this is the only known attestation of the god Mekal, and it is likely that he was very little known, if at all, in Egypt. In spite of Mekal's marginal position in Egyptian religious thought, and in spite of the fact that Beit Shean was very far from any important Egyptian religious centre, the sculptor, who inscribed the name of Mekal on the stela, added to his name the divine classifier 5 , which indicates that Mekal was identified as a divine being by the creator of this personal monument.

Another member in the small group of private stelae erected by an Egyptian/Egyptianized individual in honour of a Levantine deity that are provenanced in the Levant is the Baal Zaphon Stela from Ugarit (Louvre AO 13176), ${ }^{44}$ which is a New Kingdom funerary stele dated probably to the Nineteenth Dynasty (Levy 2014, 305), depicting its owner, Mami, worshipping Baal-Zaphon. The stela, which is inscribed with Egyptian hieroglyphs, bears the name of Baal-

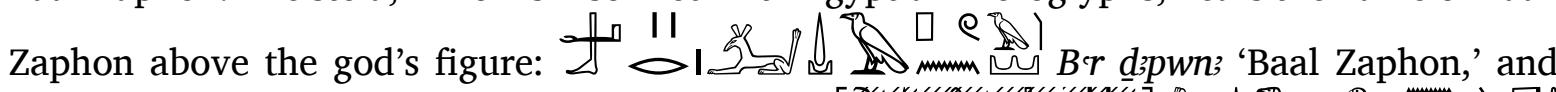
within the offering formula, which opens with [ [htp di nisw] Brr dispwn; ntrr "; 'a boon which the king gives and Baal Zaphon, the Great God $[\ldots]^{45}$ The use of the Seth animal $5^{2}-5$ (EG E21)/ 1 (EG E20) clearly indicates the divine status of Baal Zaphon and his assimilation with the Egyptian Seth.

All the examples adduced above use divine classifiers. But, alas, in many other occurrences of divine names the classifiers were dropped. This is the case with Reshef on personal monuments (Tazawa 2009, 38-59; Helck 1962, 486-87, 503-4) where his name is not necessarily followed by a divine classifier. This is also true for many other Canaanite and Egyptian divine names. As I mentioned above, classifiers are not mandatory, and their absence must not be taken to imply the lack of divinity. Yet, divine classifiers, even if they are only used in part of the occurrences, are an excellent instrument to understand the classification of a name as divine.

43 For the date and the relations of Mekal with other Canaanite deities, namely Baal and Reshef, see Levy (2018).

44 For other stelae in this group, see Levy $(2014,309)$.

45 The darkened part in square brackets marks a lacuna. For reconstruction, see Levy (2014). My translation of the offering formula differs from Levy $(2014,297)$. 


\section{West Semitic Divine Names in Egyptian Lists of Toponyms and in Personal Names}

The first toponym that pops up is Beit Anat. ${ }^{46}$ Beit Anat was named after the Canaanite goddess Anat, and was probably her cult centre. In spite of her foreign origin, Anat was a well-known royal goddess in Egypt under the reign of Ramesses II (1279-1213 BCE), who is known for his special relations with this Canaanite goddess. Ramesses II erected royal monuments in her honour, ${ }^{47}$ and presented himself as her son. Moreover, he named his eldest daughter 'Bint Anat,' 'The Daughter of Anat,' his thirty-eighth son 'Mahir Anat' (Tazawa 2009, 133), and possibly another son 'Ben Anat' 'The Son of Anat' (KRI II 907:11). ${ }^{48}$ He even named his dog Anat-em-Akhet (Tazawa 2009, 133). No doubt, Anat was one of the king's favourite goddesses and consequently one of the most important royal goddesses in the time of Ramesses II.

The Canaanite toponym Beit Anat appears on four topographical lists of King Seti I of the Nineteenth Dynasty (1294-1279 BCE), and on six lists of his son, King Ramesses II. In most of these occurrences the orthography is identical or very similar

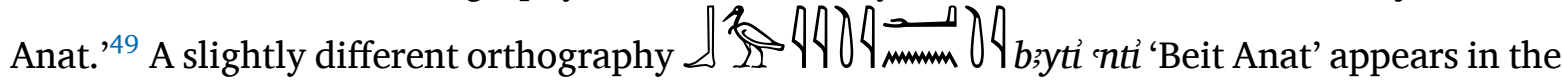
list of the temple of Seti I in Abydos. ${ }^{50}$ An additional attestation $\int 4004 \square$ mmm 'nti 'Beit Anat' appears in the Ramasseum, as part of a list of Syro-Palestinian towns captured by King Ramesses II in his Syrian campaign, in the eighth year of his reign. ${ }^{51}$ Beit Anat is an interesting example. Most of its attestations are bare of divine classifiers, and yet in the Ramasseum the divine classifier appears after the name Anat. One should emphasize that Anat here does not appear as a dedicatee of a monument. Her name is part of a list of captured enemy towns. Yet, probably because of her status as a venerated goddess in Egyptian religious thought, the cobra sign was added, thus reflecting the way in which Anat was perceived by the scribe who composed/copied that list. ${ }^{52}$

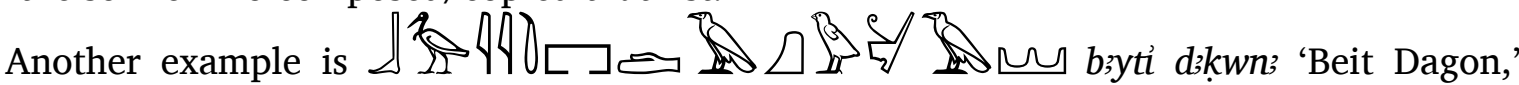
which is attested on the south pylon of Medinet Habu, where King Ramesses III is seen standing before Amun-Re, smiting his enemies (KRI V, 95, no. 72; Breasted 1932, pl. 101). The names of the enemy's towns are encircled in cartouches with the upper human body of a bound enemy. One of these towns was Beit Dagon, named after the god Dagon, and probably his cult centre. As one can easily detect, there is no divine classifier after the name Dagon, and yet we are sure that Dagon was recognised as a god in Egypt, at least by some. The reason we can be certain about Dagon's status as a divine being in Egypt is the fact that his name ap-

46 For identification and excavations, see Hasel (1998, 132-33).

47 See, for example, Louvre AF 2576 and Cairo JE 6336 in Tazawa (2009, 74).

48 See O. Louvre 2262.

49 KRI I 32:5, 29:5, 33:14; KRI II 1787:9, 178:9, 163:15. For further details, see Hasel (1998, 132-33, 170-71).

50 See west wall of the second hypostyle hall, on the southern thickness of the doorway to the chapel of King Seti I in KRI 1, 32,12,3; Calverley (1958, pl. 32). It is possible that one of the fragments in the Soleb shows 'Beit Anat,' however, this is impossible to determine with the current state of the block. For a good photograph and further reference, see Kennedy (2019, 108, fig 3).

51 The name was recorded on the first pylon of the west face of the Ramasseum, see KRI II, 148:10. Please note that here the classifier following the word 'Beit' 'House' is a complete rectangle, in difference from

the normal house classifier $\square$. 
pears in the theophoric name possibly means 'The Servant of Dagan.' The Egyptian construction of theophoric names of this pattern, i.e., $p r+$ divinity name, is well known since the Eleventh Dynasty. ${ }^{54}$ In spite of the fact that Dagon was a Canaanite god, not widely known is Egypt, someone in Egypt was named after him. This in itself is enough to testify to Dagon's divine nature.

Combing through examples of personal names from the time of the New Kingdom, one can find a few examples of personal names constructed with the names of Canaanite deities. The above discussed theophoric pattern of $p r+$ divinity name occurs in the names 68),

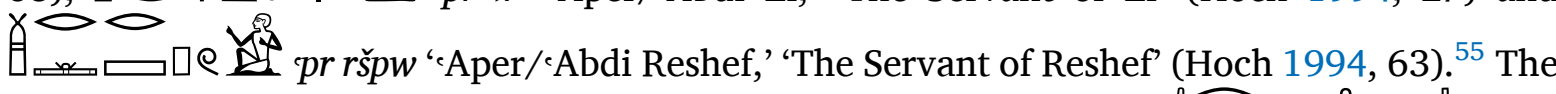
Egyptian pattern of divinity name $+m+h b$ appears in the names $h b$ 'Astarte is in Feast' (Schneider 1992, 75) and $\stackrel{2}{=}$ ? $n t m b h b$ 'Anat is in Feast' (Schneider 1992, 75). Finally, the names

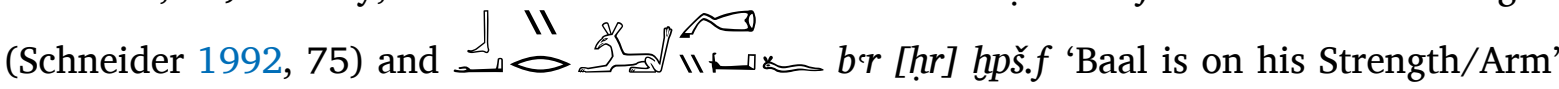
(Schneider 1992, 88) ${ }^{56}$ are also part of this list. This list is by no means exhaustive, but it demonstrates that Dagon was not an isolated instance, and names of Canaanite deities were indeed used in Egyptian theophoric names.

\section{Conclusion}

In light of the evidence adduced above, it is obvious that there were several Egyptian ways to express veneration of divine beings, a detailed analysis of which is beyond the scope of this paper. However, a few expressions of religious feelings to the Canaanite deities emerge from the foregoing discussion. The first is the dedication of monuments to Canaanite gods. The second is the use of Egyptian divine classifiers for Canaanite divine names. The third is the use of Canaanite divine names in Egyptian patterns of theophoric names. One of these expressions of religious sentiment towards a god would suffice to determine his or her acceptance as a divine being in Egypt. Such is the case of Dagon, whose name is part of an Egyptian pattern of theophoric names, which thus indicates that Dagon was received as a god in Egypt.

As for the name YHWA/YHA/YH from the topographical lists, no monument, royal or private, in Egypt or abroad, was made in his honour. His name is never followed by a divine classifier, and it does not appear in Egyptian patterns of theophoric names. One may argue that the personal name of the owner of the Book of the Dead 'Adoni Roae Yah' is an indication of a certain acquaintance with 'Roae Yah' 'the Shepherd of Yah' as a divine being. This, however, is not the case. The sentence name is recorded only once, and its pattern was not familiar to the Egyptians. Moreover, the name, which is written in Egyptian signs, records a

$53 \quad$ For suggesting and discussing ‘Abdi, see Hoch (1994, (71), 63-65).

54 For further examples, see Hoch (1994, 63-65).

55 Please note that above the sign $\square$, there is a Hieratic sign resembling a small crescent; see Hoch $(1994,63)$. $\approx$

56 Please note that $\ \longleftarrow$ is written with a Hieratic sign similar to $E G \mathrm{Z} 4$, rather than $E G \mathrm{Z} 4$. 
west Semitic language. 'Roae Yah' does not reveal who the god behind the epithet is, and consequently, the occurrence of the personal name 'Adoni Roae Yah' does not imply an Egyptian acquaintance with Yah.

Finally, the noun 'Beit' 'house,' which precedes the divine name in the topographical lists, may denote the existence of a sanctuary for the god in the town, and hence reflect the deity's status as divine in Canaan. Thus, Beit Anat was probably a place with a sanctuary to the goddess Anat, whereas Beit Dagon was the cult centre of the god Dagon. For this reason, Giveon suggested that "The toponym Yahweh must have developed from a form like 'Beth Yahweh'[...]." ${ }^{57}$ Nevertheless, there is no indication whatsoever for the existence of 'Beit YHWA/YHA/YH' in Canaan between the first attestation of the name YHWA in the Soleb lists, dated to the reign of Amenhotep III, and the appearance of YHA in Medinet Habu in the list of Ramesses III (1390-1153 BCE).

The inevitable conclusion from all the material adduced above is that in Egypt of the New Kingdom, YHWA/YHA/YH was not known as a deity. Furthermore, based on the topographical lists and other Egyptian material, there are no indications for YHWA/YHA/YH's divinity, neither in Canaan nor in any other part of the world. As much as the Egyptian data lure many scholars to speculate on the origins of $\mathrm{YHWH}$, the biblical god of the Hebrews, and on the traces he left in the Egyptian topographical lists, one must acknowledge the very limited nature of these records, which do not permit any conclusion beyond the geographical association of YHWA/YHA with the Shasu. Anything beyond that belongs to the realm of fantasy.

\section{References}

Adrom, Faried, and Matthias Müller. 2017. "The Tetragrammaton in Egyptian Sources - Facts and Fiction." In The Origins of Yehwism, edited by Jürgen van Oorschot and Markus Witte, 93-113. Berlin/Boston: De Gruyter.

Ahituv, Shmuel. 1984. Canaanite Toponyms in Ancient Egyptian Documents. Jerusalem: Magnes. Allon, Niv. 2007. "Seth Is Baal - Evidence from the Egyptian Script." Egypt and the Levant 17: 15-22.

Astour, Michael C. 1979. "Yahweh in Egyptian Topographical Lists." In Festschrift Elmar Edel, edited by Görg Manfred and Edgar Pusch, 17-33. ÄAT 1. Bamberg: Görg.

Breasted, James Henry. 1932. Medinet Habu. Vol. 2. Historical Records of Ramses III, OIP IX. Chicago: OIP.

Budin, Stephanie L. 2015. "Qedeshet: A Syro-Anatolian Goddess in Egypt.” Journal of Ancient Egyptian Interconnections 7 (4): 1-20.

Calverley, Amice M. 1958. The Temple of King Sethos I at Abydos. Vol. 4: The Second Hypostyle Hall. London/Chicago: The Egypt Exploration Society/The Oriental Institute of the University of Chicago.

57 Giveon R., “"The Cities of Our God” (II Sam 10:12),' Journal of Biblical Literature 83:4 (1964), 415-416, see also Grdseloff, "Édôm, d'après les sources égyptiennes," 69-99, at 81-82, about "l'existence d'une ville Jahwa en territoire kénite, ce qui rend l'origine kénite du culte de Jahwa encore plus probable." — the existence of a town of YHWH in Kenite territory makes the Kenite origin of the cult of YHWH even more likely; Ahituv S., Canaanite Toponyms in Ancient Egyptian Documents (1984), 22 "(t)he SAsw-land of Jahu (Yāhū) is the wandering area of the clan of the worshippers of Yāhū, the God of Israel. It most probably pertains to the region of Kadesh-barnea and Jebel Hilāl, which might be the sacred Mt. Sinai." 
Cornelius, Izak. 2008. The Many Faces of the Goddess: The Iconography of the Syro-Palestinian Goddesses Anat, Astarte, Qedeshet, and Asherah C. 1500-1000 BCE. OBO 204. Fribourg/Göttingen: Academic Press/Vandenhoeck \& Ruprecht.

Edwards, Iorwerth Eiddon. 1955. "A Relief of Qudshu-Astarte-Anath in the Winchester College Collection.” JNES 14 (1): 49-51.

Fleming, Daniel E. 2021. Yahweh Before Israel. Glimpses of History in a Divine Name. Cambridge UK: Cambridge University Press.

Flynn, Shawn W. 2020. A Story of YHWH, Cultural Translation and Subversive Reception in Israelite History. London/New York: Routledge.

Frevel, Christian. 2021. "When and from Where Did YHWH Emerge? Some Reflections on Early Yahwism in Israel and Judah." Entangled Religions 12 (2). https://er.ceres.rub.de/ index.php/ER/article/view/8776.

Gardiner, Alan H. 1911. Egyptian Hieratic Texts, Transcribed, Translated and Annotated, Series I: Literary Texts of the New Kingdom, the Papyrus Anastasi I and the Papyrus Koller, Together with the Parallel Texts. Leipzig: J.C. Hinrichs.

1917. "The Tomb of Much-Travelled Theban Official." JEA 4 (1 (January)): 28-38.

1957. Egyptian Grammar Being an Introduction to the Study of Hieroglyphs. 3rd ed. Oxford: Oxford University Press.

Giveon, Raphael. 1964. “'The Cities of Our God' (II Sam 10:12).” Journal of Biblical Literature 83 (4): 415-16.

—. 1971. Les Bédouins Shosou des documents égyptiens. Vol. 18. Documenta et monumenta Orientis antiqui. Leiden: E.J. Brill.

- 1978. "Determinatives in the Hieroglyphic Writing of Canaanite Names." In The Impact of Egypt on Canaan: Iconographical and Related Studies, by Raphael Giveon, 15-21. OBO 20. Fribourg/Göttingen: Academic Press/Vandenhoeck \& Ruprecht.

Goldwasser, Orly. 2002. Prophets, Lovers and Giraffes: Wor(l)d Classification in Ancient Egypt. Göttinger Orientforschungen IV. Reihe Ägypten, 38, Vol. 3. Wiesbaden: Harrassowitz.

Görg, Manfred. 1976. “Jahwe - ein Toponym?” BN 1: 7-14.

Grdseloff, Bernhard. 1947. "Édôm, d'après les sources égyptiennes." Revue del l'histoire juive en Égypte 1: 69-99.

Hasel, Michael G. 1998. Domination and Resistance, Egyptian Military Activity in the Southern Levant ca. 1300-1185 B.C. Probleme Der Ägyptologie 11. Leiden/Boston/Köln: Brill.

Hayes, William C. 1990. The Scepter of Egypt II: The Hyksos Period and the New Kingdom (16751080). New York: The Metropolitan Museum of Art.

Helck, Wolfgang. 1962. Die Beziehungen Ägyptens zu Foederasien im 3. Und 2. Jahrtausend v. Chr. Ägyptologische Abhandlungen 5. Wiesbaden: Otto Harrassowitz.

Hoch, James E. 1994. Semitic Words in Egyptian Texts of the New Kingdom and Third Intermediate Period. Princeton: Princeton University Press.

Kelley, Justin. 2009. "Toward a New Synthesis of the God of Edom and Yahweh." Antiguo Oriente 7: 255-80.

Kennedy, Titus. 2019. "The Land of the SAsw (Nomads) of yhwA at Soleb." Dotawo: A Journal of Nubian Studies 6 (1): 175-92. https://escholarship.org/uc/item/07x6659z.

Kitchen, Kenneth Anderson. 2009. "Egyptian New-Kingdom Topographical Lists: An Historical Resource with 'Literary Histories'." In Causing His Name to Live: Studies in Egyptian Epigraphy and History in Memory of William J. Murnane, edited by Peter Brand and Louis Cooper, 129-35. Leiden: Brill. 
- 1968-1983. Rammeside Inscriptions I-V. Oxford: Blackwell LTD.

Knauf, Ernst-Axel. 1984. "Qaus in Ägypten." Göttinger MIszellen 73: 33-36.

—. 1999. "Qôs." In Dictionary of Deities and Demons in the Bible, edited by Karl Van der Toorn and Peter W. Van der Horst, 2nd ed., 674-7. Leiden/Boston/Cologne: Brill/Grand Rapids.

Leitz, Christian. 2002. Lexikon der ägyptischen Götter und Götterbezeichnungen. Vol. 2. Leuven/Paris/Dudley, MA: Peeters.

Levy, Eythan. 2014. "A Fresh Look at the Baal Zaphon Stele.” The Journal of Egyptian Archaeology 100: 293-309.

—. 2018. "A Fresh Look at the Mekal Stele." Ägypten und Levante [Egypt and the Levant] 28: 359-78.

Miller, Robert D. II. 2021. Yahweh: Origin of a Desert God. Forschungen Zur Religion Und Literatur Des Alten Und Neuen Testaments 284. Göttingen: Vandehoeck \& Ruprecht.

Morris, Ellen Fowles. 2005. The Architecture of Imperialism Military Bases and the Evolution of Foreign Policy in Egypt's New Kingdom. Probleme der Ägyptologie 22. Leiden/Boston: Brill.

Oded, Bustenay. 1971. "Egyptian References to the Edomite Deity Qaus." Andrews University Seminary Studies 9: 47-50.

Redford, Donald Bruce. 1992. Egypt, Canaan, and Israel in Ancient Times. Princeton: Princeton University Press.

Schiff-Giorgini, Michela, and Clément Robichon. 1998. Soleb III: Le temple - description. Bibliothèque générale 19. Cairo: IFAOSchi.

—. 2002. Soleb V: Le temple - bas-reliefs et inscriptions. Bibliothèque générale 23. Cairo: IFAO.

Schneider, Thomas. 1992. Asiatische Personennamen in ägyptischen Quellen des Neuen Reiches. Orbis Biblicus et Orientalis 114. Fribourg/Göttingen: Universitätsverlag Freiburg/Vandenhoeck \& Ruprecht.

- 2008. "The First Documented Occurrence of the God YAHWEH? (Book of the Dead Princeton 'Roll 5').” JANE 7: 113-20.

Shalomi-Hen, Racheli. 2000. Classifying the Divine, Determinatives and Categorisation in CT 335 and BD 17. Göttinger Orientforschungen IV. Reihe Ägypten 38, Vol. 2. Wiesbaden: Harrassowitz Verlag.

Shaw, Ian. 2000. "Chronology." In The Oxford History of Ancient Egypt, 479-83. Oxford: Oxford University Press.

Simons, Jan Jozef. 1937. Handbook for the Study of Egyptian Topographical Lists Relating to Western Asia. Leiden: Brill.

Smith, Mark S. 2017. "YHWH's Original Character: Questions About an Unknown God." In The Origins of Yehwism, edited by Jürgen van Oorschot and Markus Witte, 23-43. Berlin/Boston: De Gruyter.

Stadelmann, Rainer. 1967. Syrisch-palästinensische Gottheiten in Ägypten. Probleme der Ägyptologie 5. Leiden: Brill.

Taylor, Ian Robert. 2016. "Deconstructing the Iconography of Seth.” PhD diss., Birmingham: Birmingham University.

Tazawa, Keiko. 2009. Syro-Palestinian Deities in New Kingdom Egypt, the Hermeneutics of Their Existence. BAR International Series 1965. Oxford: BAR. 
Te Velde, Hermann. 1967. Seth, God of Confusion. A Study of His Role in Egyptian Mythology and Religion. Leiden: Brill.

Weippert, Manfred. 1974. "Semitische Nomaden des zweiten Jahrtausends. Über die SAsw der ägyptischen Quellen.” Biblica 55: 265-80. 